\title{
Uncovering Evidence for Endocrine-Disrupting Chemicals That Elicit Differential Susceptibility through Gene-Environment Interactions
}

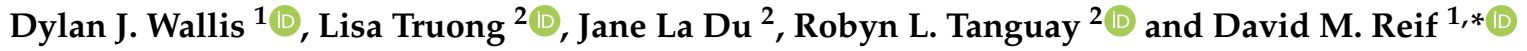 \\ 1 Department of Biological Sciences, North Carolina State University, Raleigh, NC 27695, USA; \\ djwallis@ncsu.edu \\ 2 Department of Environmental and Molecular Toxicology, Oregon State University, Corvallis, OR 97331, USA; \\ lisa.truong@oregonstate.edu (L.T.); jane.ladu@oregonstate.edu (J.L.D.); \\ robyn.tanguay@oregonstate.edu (R.L.T.) \\ * Correspondence: dmreif@ncsu.edu
}

Citation: Wallis, D.J.; Truong, L.; La Du, J.; Tanguay, R.L.; Reif, D.M. Uncovering Evidence for EndocrineDisrupting Chemicals That Elicit Differential Susceptibility through Gene-Environment Interactions. Toxics 2021, 9, 77. https://doi.org/ $10.3390 /$ toxics 9040077

Academic Editor: Miguel

Machado Santos

Received: 3 March 2021

Accepted: 2 April 2021

Published: 6 April 2021

Publisher's Note: MDPI stays neutral with regard to jurisdictional claims in published maps and institutional affiliations.

Copyright: (c) 2021 by the authors. Licensee MDPI, Basel, Switzerland. This article is an open access article distributed under the terms and conditions of the Creative Commons Attribution (CC BY) license (https:/ / creativecommons.org/licenses/by/ $4.0 /)$.

\begin{abstract}
Exposure to endocrine-disrupting chemicals (EDCs) is linked to myriad disorders, characterized by the disruption of the complex endocrine signaling pathways that govern development, physiology, and even behavior across the entire body. The mechanisms of endocrine disruption involve a complex system of pathways that communicate across the body to stimulate specific receptors that bind DNA and regulate the expression of a suite of genes. These mechanisms, including gene regulation, DNA binding, and protein binding, can be tied to differences in individual susceptibility across a genetically diverse population. In this review, we posit that EDCs causing such differential responses may be identified by looking for a signal of population variability after exposure. We begin by summarizing how the biology of EDCs has implications for genetically diverse populations. We then describe how gene-environment interactions $(\mathrm{GxE})$ across the complex pathways of endocrine signaling could lead to differences in susceptibility. We survey examples in the literature of individual susceptibility differences to EDCs, pointing to a need for research in this area, especially regarding the exceedingly complex thyroid pathway. Following a discussion of experimental designs to better identify and study GxE across EDCs, we present a case study of a high-throughput screening signal of putative GxE within known endocrine disruptors. We conclude with a call for further, deeper analysis of the EDCs, particularly the thyroid disruptors, to identify if these chemicals participate in GxE leading to differences in susceptibility.
\end{abstract}

Keywords: endocrine-disrupting chemical (EDC); gene-environment interaction (GxE); differential susceptibility

\section{Introduction}

The EDCs are a broad class of compounds that have emerged in the last several decades as an imminent threat to human health. Over ten years ago the Endocrine Society released their first Scientific Statement on EDCs [1]. Since the publication of that article, the number of papers published on these chemicals has increased every year. According to one study, the estimated cost of exposure to EDCs in the US was $\$ 340$ billion dollars [2].

The Endocrine Society, in their second Scientific Statement, defines an endocrinedisrupting chemical as "an exogenous chemical, or mixture of chemicals, that interferes with any aspect of hormone action" [3]. This interference has been shown to cause a range of negative effects, including impacts on cardiovascular health, metabolic health, reproductive health, prostate gland function, thyroid function, and neurodevelopment [3-6]. Despite their deleterious effects, endocrine-disrupting chemicals are present in a wide array of consumer products that most people encounter every day, including cosmetics, personal care products, pesticides, packaging, and building materials [7-13]. 
Many diseases that are associated with EDCs, such as obesity and type 2 diabetes, have known genetic risk factors $[14,15]$. EDCs have diverse mechanisms of action. They can affect protein and gene expression via interaction with a multitude of biological pathways [3], suggesting the possibility of genetic differences being able to modulate the effects of endocrine disruptors via GxE.

Some of the effects of EDCs already have well-characterized gene-environment interactions that modulate an organism's susceptibility [16-19]. This is only a drop in the bucket of the many endocrine-disrupting chemicals that may participate in GxE. The advent of toxicogenomics and personalized medicine underscores the importance of understanding individual differences across populations in the effects of chemical exposure [20,21]. Understanding which EDCs are involved in GxE and what genetic factors contribute to susceptibility can yield a better understanding of risk, a better grasp on the chronic and acute effects of a chemical, a more diverse regulatory environment, as well as increasing knowledge about the mechanisms by which a chemical disrupts biological pathways. This is especially important in endocrine disruptors because their complex and varied mechanisms and effects can often cause challenges to current research and risk assessment [22].

In this paper we will discuss endocrine-disrupting chemicals and the mechanisms by which they may cause differential susceptibility in a population that is caused by population-wide genetic differences, focusing on thyroid disruption. We will then discuss methods by which chemicals that display gene-based, population-wide differences can be identified, and then the genetic etiology of these differences can be found.

\section{Biology of Endocrine-Disrupting Chemicals and Implications for Diverse Populations}

2.1. History and Exposure

When diethylstilbestrol (DES) was found to cause cancer in the daughters of mothers that took it, a new era in toxicology had begun [23]. EDCs are now ubiquitous in the built environment [7-13]. They are present in a wide array of the products we use daily in many different forms that can affect the endocrine system in myriad ways. The most famous and first studied class of endocrine disruptors is estrogenic EDCs like DES [23,24].

\subsection{Molecular Biology of EDCs}

The study of EDCs has since gone beyond estrogen-active chemicals. Compounds have been identified that affect several of the nuclear hormone receptors (NR) including the estrogen receptor (ER), androgen receptor (AR), the glucocorticoid receptor (GR), the mineralocorticoid receptor (MR), the thyroid receptor (TR), and the peroxisome proliferatoractivated receptor (PPAR) [25-29]. These receptors contain a ligand-binding domain (LBD), that recognizes and binds discrete ligands, and a DNA binding domain (DBD), which binds a specific DNA sequence as either a homodimer or heterodimer, after a ligand is bound [30]. The specific DNA sequence bound by an NR is known as a hormone response element (HRE) [30].

HREs, in general, are arranged as hexameric repeats [31]. These repeats can be direct, inverted, or everted hexamers with a spacer of length 3 or more in between them [31-36]. Within the nuclear receptors, these consensus sequences are often shared $[33,37,38]$. For example, the AR and GR share the exact same sequence as their response element $[37,38]$. Specificity of NR binding is imparted via a number of mechanisms. Experiments that created mutations in a given HRE show that changes in the consensus sequence, especially of the first hexamer in the repeat, can make an HRE more or less specific to a certain NR $[33,36,39]$. The distance between repeats can also change the specificity of an HRE $[32,36]$. The orientation or composition of an NR dimer can also change based on the orientation of the HRE [32,36]. Going beyond the consensus sequence of an HRE, the base pairs that flank the hexameric repeats may exert a level of specificity to an HRE [34].

Binding to their respective response elements allows NRs to modulate many physiological functions via transcriptional control of certain genes [40]. Endocrine-disrupting 
chemicals that act on NR can act as agonists, activating the receptor by mimicking its ligand, or as antagonists, in some way preventing the activity of the receptor [29,41-43]. Some well-known EDCs include bisphenol A, a widely discontinued plastic and resin additive; DDT, a pesticide that is used around the world; estradiol, the first endogenous estrogenic hormone to be synthesized; Genistein, a phytoestrogen; tamoxifen, a non-steroidal estrogen that has been used for breast cancer treatment; and phthalates, a class of chemicals used in many industrial applications [10,41,44-47]. As more chemicals are tested for endocrine disruption the list continues to grow. A recent effort by the EPA to screen almost 2000 chemicals using computational methods and comparing them to known estrogens identified 111 compounds for further investigation [43]. A similar study found 220 chemicals that exhibited AR receptor agonism or antagonism as well as 174 more chemicals that may be weakly active in the AR pathway [42]. While direct interactions with NRs and their binding sites are common mechanisms of endocrine disruption there are several other ways they may interact across these pathways that could be subject to genetic effects. These mechanisms include inhibition or stimulation of hormone synthesis, changes in the hormone binding, binding of hormone-binding proteins, and stimulation or inhibition of hormone-binding protein synthesis [47].

\subsection{Effects on Biological Pathways}

The many different EDCs, with their disparate functions and structures, can work via several different pathways based on which receptors they interact with. Estrogenic compounds, in some way, mimic endogenous compounds that bind to the ER. Depending on structure these chemicals can bind to either estrogen receptor alpha (ER $\alpha)$ or estrogen receptor beta $(E R \beta)$ causing differing effects $[45,48]$. Estrogen signaling affects several pathways and differs based on the localization of the ER in different tissues and locations within the cell [24,49]. Many estrogenic EDCs act as estrogen receptor agonists or antagonists throughout the body $[24,45,48]$. Some act differently depending on the tissue in which they are localized. These are known as selective estrogen receptor modulators or SERMs [44,50]. ER $\alpha$ and ER $\beta$ signaling has profound effects on multiple biological systems. Activation and antagonism of these receptors can affect the development and upkeep of sexual organs, the lungs, adipose tissue, the immune system, and the brain [51,52]. These effects are produced when these signals are propagated across a diverse array of signaling pathways [53].

The AR shares a superfamily designation with many other NRs including the ER [30]. Much like the ER, the AR plays an important role in the regulation and upkeep of important biological processes [54]. These processes include the development and function of sexual organs, cognitive and sexual behavior, brain patterning, hair patterning, and muscular development and upkeep [54-59]. The primary hormones that act as AR agonists are testosterone and $5 \alpha$-dihydrotestosterone, a metabolite of testosterone [55]. Although antiandrogens are better studied, androgen disrupting chemicals can bind the AR and act as agonists or antagonists [26,42,60]. In addition to being modulated by ligands and having specific elements with high affinity, the AR is similar enough to the progestin and glucocorticoid receptor which allows to share response elements with them [54,61-63]. The AR can also bind a variety of response elements on the DNA via the differing orientation of the homodimer formed after ligand binding to modulate a number of genes [63].

The activity of thyroid hormones is regulated by a complex web of feedback loops. In short, the thyroid gland is stimulated to produce thyroid hormones via thyroid-stimulating hormone (TSH) from the pituitary [64,65]. Thyroid hormone receptors (TRs) are acted on by thyroid hormones around the body, primarily triiodothyronine (T3) and thyroxine (T4) [64]. TSH secretion is, itself, regulated by levels of thyroid hormone circulating in the bloodstream $[64,65]$. Thyroid hormone receptors (TRs) localize in multiple cell types across the body $[65,66]$. Much like the ER, the TR has multiple isoforms [65-68]. These isoforms are splice products that are coded by two different genes at two different chromosomes each one localizing and functioning in different ways [65-68]. TR $\alpha 1, \operatorname{TR} \beta 1, \operatorname{TR} \beta 2$, and TR $\beta 3$ all 
bind T3 while TR $\alpha 2$, TR $\alpha 3$ do not $[67,68]$. Beyond localization and structure, the effects of the TR can be further modulated by the recruitment of corepressors and coactivators, and interaction with other signaling pathways beyond the thyroid [69-71]. This complex system plays an important role in growth and development, neural differentiation, and metabolic regulation $[64,65,71-74]$.

With such diverse pathways within which these nuclear hormones play a definitive role, endocrine disruptors could mediate a multitude of effects on biological systems, leading to substantial consequences to exposure. In fact, in the time that endocrine disruptors have been studied it has been shown that they may lead to metabolic, neurological, reproductive, and cardiovascular dysfunctions, as well as cancer [3]. Studies have shown that exposure to EDCs such as persistent organic pollutants (POPs) and DES, especially during development, can lead to obesity via interaction with nuclear hormone receptors $[4,75]$. Obesity itself can also lead to differences in the effects of EDC exposure. Endocrine disruptors are extremely lipophilic and are therefore stored in fat cells, this can lead to an increased body burden of endocrine disruptors in people who are obese [4]. Although limited, studies have tied autism spectrum disorder to prenatal exposure to EDCs [76]. Dichlorodiphenyldichloroethylene ( $p, p^{\prime}$-DDE) has been linked to an increased risk of diabetes $[77,78]$. EDCs have been shown to negatively affect neurological development after pre- and peri-natal exposure, oftentimes through disruption of the thyroid signaling pathway [79-81]. In fact, the life stage in which exposure occurs can drastically affect an individual's susceptibility to that chemical $[4,75,82-84]$. If exposure occurs during a "window of susceptibility" or not can exacerbate or ameliorate the future effects of exposure $[4,75,82-84]$. The time in which someone is exposed to certain EDCs has been shown to have a large effect on the development of metabolic disorders such as obesity and type 1 diabetes, or if they develop specific cancers such as breast cancers $[4,75,82-84]$. These windows of susceptibility have a serious impact on how research into individual susceptibility to EDCs should be done. Life stages for research should be chosen carefully to capture the desired effect. Endocrine disruptors themselves, especially phthalates, have repeatedly been tied to childhood asthma [82-84]. BPA has been associated with reproductive dysfunction in humans [85]. Several studies tied dioxin to cardiovascular disease mortality [86]. As far as cancer is concerned, EDCs have been tied to the development of multiple types of cancer including vaginal, prostate, breast, ovarian, and cervical cancers [23,87-93]. A more detailed look into estrogenic, androgenic, and thyroid disruptors and their effects can be found in Kiyama and Wada-Kiyama [24], Luccio-Camelo and Prins [26], and Calsolaro et al. [94] and The Endocrine Society's Second Scientific Statement on Endocrine-Disrupting Chemicals [3].

\subsection{Implications for Population Diversity}

With so many processes being regulated by the endocrine system and NRs themselves, it comes as no surprise that disruption of any of these systems can cause such a wide range of effects [50-58,63-73]. Not surprisingly, the effects of EDCs are not limited to any area of the body or a family of diseases $[3,4,23,74-89]$. The NRs exist within complex systems of tightly controlled interactions that modulate a diverse array of systems across the body [50-58,63-73]. These systems hinge on the interactions between the receptors and a small number of consensus sequences throughout the human genome [25-46]. These sequences, along with the sequences that code for the receptors, must be subject to the same standing variation in the population that exists across the human genome. These effects cascade across multiple biological systems that are also subject to the effects of changing genetics [50-58,63-73]. Differences at genetic loci in important genes have, repeatedly, been shown to be capable of causing population-level differences in susceptibility to diseases. Therefore, differences in the genetic loci that code for NRs or sequence differences in the HREs that they bind have the capability to lead to differences in susceptibility to EDCs across a genetically diverse population by affecting responses to EDC exposure. 


\section{Evidence for Differential Susceptibility to Endocrine-Disrupting Chemicals}

The genetic nature of the NRs influence on complex biological systems implies the possibility of genetic differences having far-reaching effects on the influence of EDCs on different aspects of those same systems. While sparse, emerging studies suggest that genetic differences can lead to response differences following EDC exposures.

Several studies in rats have shown that differences across strains demonstrated a marked difference in perturbation to the endocrine system [95-100]. One rat study found that exposure to 2,4,5,2, $4^{\prime}, 5^{\prime}$-hexachlorobiphenyl (HCB) caused increased expression of multiple cytochrome p450 enzymes, but this response was suppressed by an endocrine mediated mechanism that was based partly on genetic differences in rat strains [97,98]. The endocrine-disrupting effects of 2,3,7,8-tetrachlorodibenzo- $p$-dioxin (TCDD) have also been linked to strain differences in rats, specifically relating to the aryl hydrocarbon receptor $[99,100]$. Strain differences in susceptibility to estrogen disruption in mice, specifically relating to breast cancer, have been studied and shown extensively across various strains of mice $[17,18,101,102]$. Many studies have also examined gene-environment interactions as they relate to human reproductive function. Many different chemicals have been shown to cause variable phenotypes within effects like cryptorchidism, hypospadias, testicular dysgenesis, and infertility [16,103]. Yet even these may need further investigation [16].

Compared to many biological systems, the thyroid signaling process is extremely complicated: it affects almost all cells in vertebrates, it's regulated by a complex system of feedback loops, and it contains multiple isoforms and ligands that control localization and effects of TR binding molecules [64-74]. As a result, in many cases, differential susceptibility to the thyroid effects of endocrine disruptors tends to be overlooked. Yet evidence of a genetic basis for differential susceptibility to many exposures via the thyroid system does exist within the literature. A study on asthma patients found a SNP $5^{\prime}$ to the thyroid receptor beta gene that was associated with the patient response to isopterenol [104]. One small study indicated that polymorphisms in the THRA and THRB genes were associated with autism spectrum disorder [105]. Together this may represent an indication that there are genes that create susceptibility to prenatal thyroid disruption leading to an adverse outcome. Some studies have pointed to genetic variants that may cause changes in sensitivity to thyroid hormone $[106,107]$. Mutations upstream of the THRB gene are associated with resistance to thyroid signaling $[106,107]$. One gene variant on the promoter region of a tumor necrosis factor gene, considered a risk allele for joint disorders, acts as a thyroid receptor binding site [108]. One variant at this locus appears to sensitize the region to certain stimuli, leading to joint problems [108]. This is a clear example of increased susceptibility due to a genetic variant within the thyroid signaling system. Studies in rats have also indicated clear strain differences in susceptibility to thyroid disruption. One study showed that different strains of rats showed differences in individual susceptibility to developing thyroiditis after irradiation and thymectomy [96]. Another study found that genetic differences in rats led to marked differences in responses to iodine deficiency [95]. Mutations in the thyroid receptor genes have also been tied to various varieties of cancer [109-111]. Differential responses within the thyroid signaling system are even of importance to agriculture. Differences in response to $T_{3}$ supplementation have been shown in various strains of chickens [112]. One promising study looking at susceptibility to $\mathrm{T}_{3}$ used molecular modeling combined with site-directed mutagenesis to investigate mutations in the thyroid hormone receptors that could influence $\mathrm{T}_{3}$ binding [113]. This study is a step in the right direction towards understanding differences in susceptibility to thyroid disruption.

A class of chemicals that have been widely identified as endocrine, and specifically thyroid, disruptors is the flame retardant chemicals (FRCs) [114-117]. One study screened flame retardants for developmental effects on a genetically diverse zebrafish population [118]. High variance within an endpoint across a genetically diverse population could represent GxE and be driven, partially, by heritable traits that make the fish more or less resistant to exposure. Reif et al. showed that by identifying chemicals in a high 
throughput screening that showed high variance in multiple endpoints, one could find chemicals that exhibited GxE that modulates susceptibility [119]. Closer examination of the data from the flame-retardant screening study shows that many of these flame retardants have a high variance of effect across the genetically diverse fish population. This is represented in Figure 1 which shows multiple high variances across two prevalent endpoints in FRCs at their measured lowest effect level (LEL) compared to the variability across all FRCs. Figure 1 also includes the variance of statins across a high-throughput zebrafish screening $[118,119]$. Statins have been shown to participate in GxE affecting the individual susceptibility to statins across the human population via transport pathways $[120,121]$. Statins also exhibit high variance across the same genetically diverse zebrafish population, according to another high-throughput screening study. Statins are plotted with the FRCs in Figure 1 to illustrate that the variance of effect across the population within FRCs is similar to a chemical with known GxE.

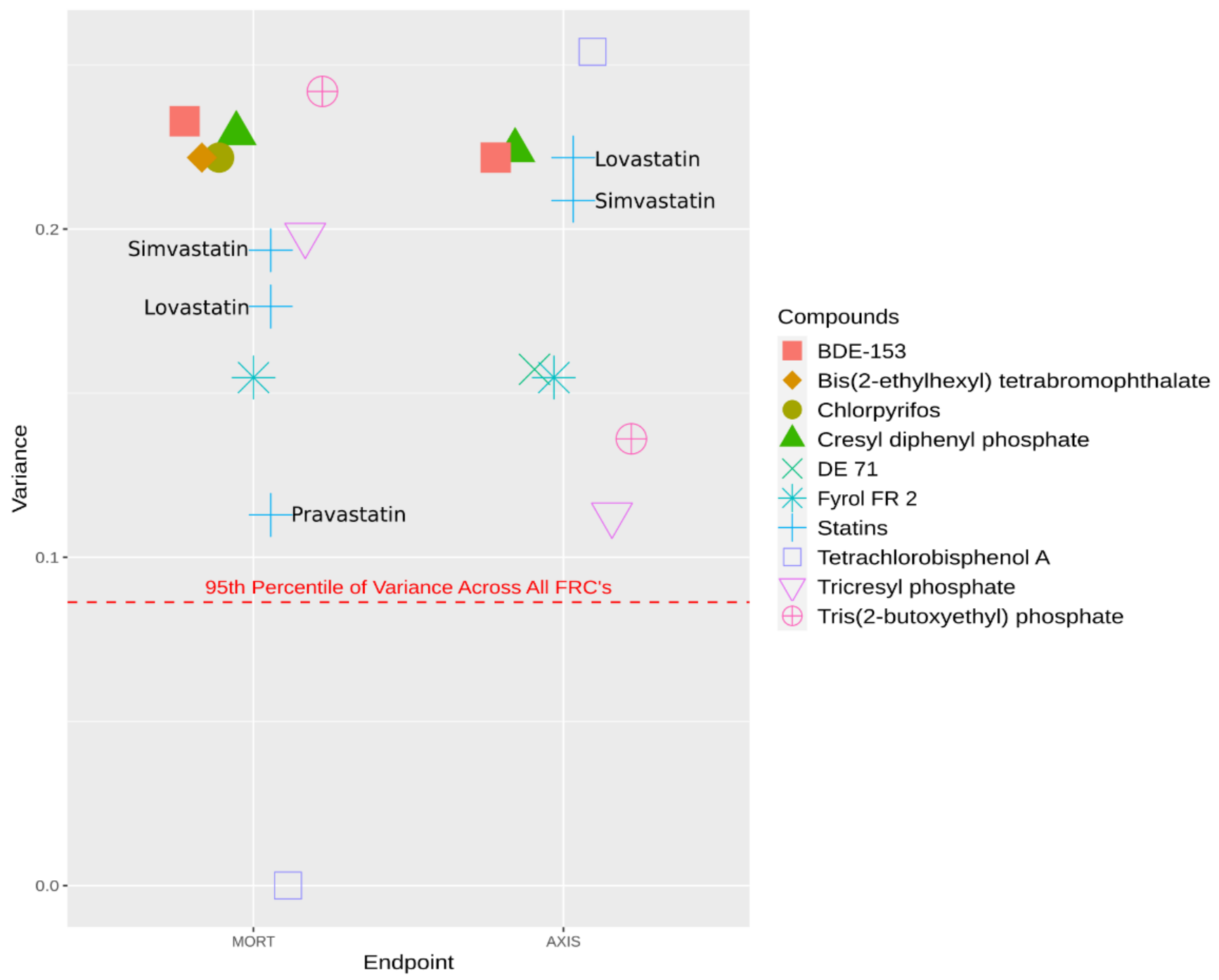

Figure 1. Variance across a high-throughput screening assay in a genetically diverse population of zebrafish across two endpoints: mortality (MORT) and bent axis (AXIS) at a chemicals lowest effect level as measured in the screening. This includes flame retardant chemicals (FRCs) that are enriched in thyroid pathways as well as statins, which are known to participate in GxE which lead to differences in susceptibility, for comparison. The statins are individually labelled. The line on the bottom represents the 95th percentile of variance in the full FRC screening. Each chemical is a different shape and color. 
The Comparative Toxicogenomics Database (CTD) shows that statins are enriched across multiple transport pathways in humans [122]. FRCs are enriched, as a whole, in several thyroid pathways, and several of the screened FRCs are shown to be individually enriched in these same thyroid pathways $[118,122]$. This is illustrated in Figure 2.

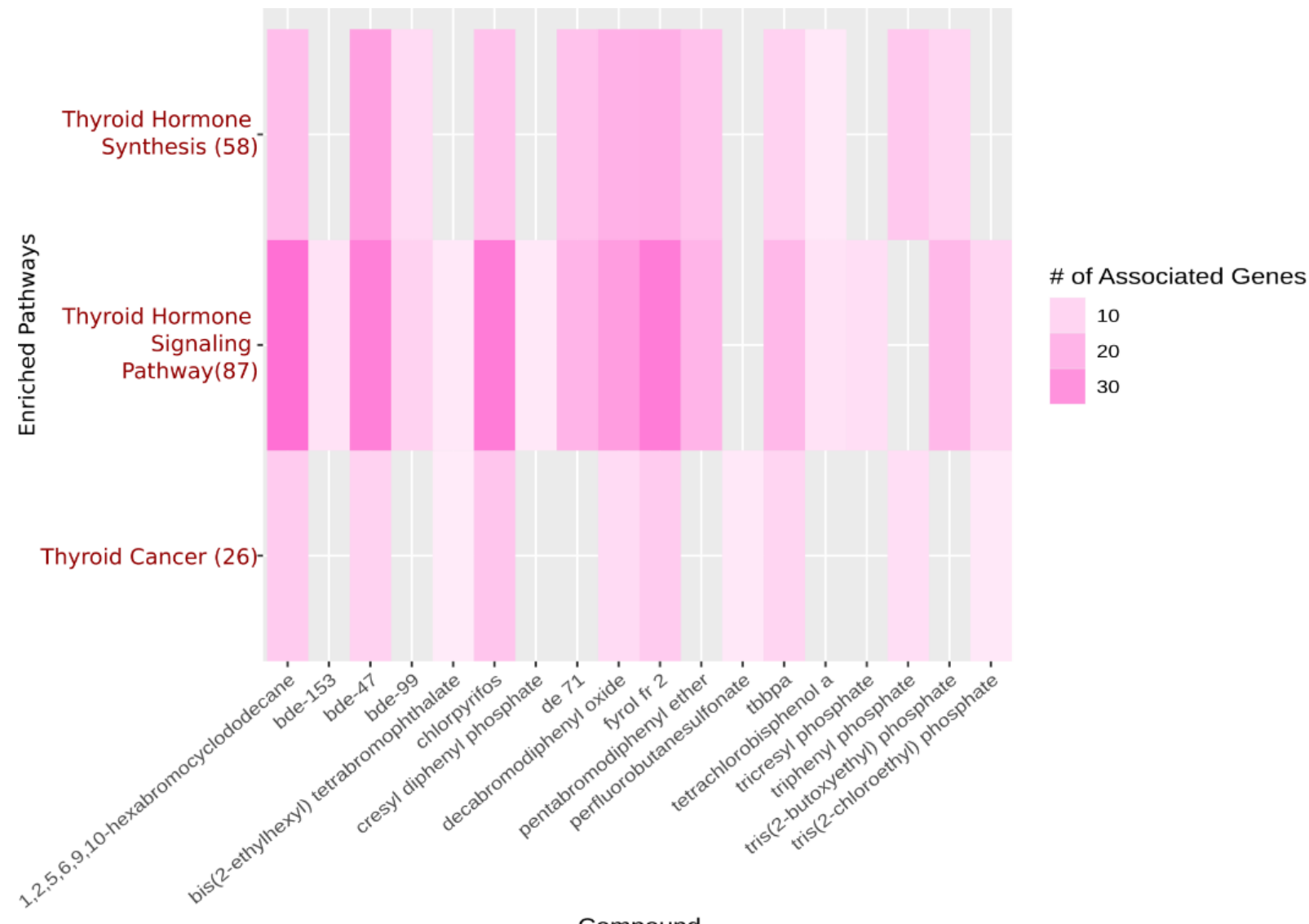

Compound

Figure 2. A heatmap displaying a pathway enrichment analysis done on CTD using FRCs that were used in a high throughput screening experiment. Individual FRCs are plotted along the $x$-axis. The $y$-axis lists the pathways that are enriched for these chemicals, with the number in parentheses indicating the number of genes in each pathway that these chemicals (taken as a whole) are enriched in. Darker coloration represents increasing numbers of genes that are associated with each FRC.

This combined enrichment, as a class and individually, in addition to high variance across a genetically diverse population may represent a signature of GxE in a chemical class. In addition, many of the highest variance flame retardant chemicals identified by this simple analysis (Figure 2), already have several studies showing endocrine-disrupting effects [123-152]. Looking at the variance of an endpoint in a high throughput screening experiment represents one way to quickly identify candidate chemicals for GxE. The FRCs represent a class of endocrine disruptors that affect the thyroid and exhibit a signature of effects that could be representative of EDCs that participate in GxE and lead to differential individual susceptibility across a population. It certainly warrants further investigation as to what classes of EDCs should be considered for deeper analysis into the possibility that they can cause a wide range of effects based on small genetic differences.

\section{Characterizing GxE Effects Associated with Endocrine-Disrupting Chemicals}

All of this information points to the strong possibility that gene-environment interactions may play a role in susceptibility to endocrine disruption by environmental exposures, but what is GxE? GxE is, simply put, how environmental exposures can be modulated by 
interaction with specific genes. The result being that one individual may respond differently to some environmental exposure than another individual in the same population with a different allele or set of alleles. As we have seen, the endocrine system is highly subject to the influence of genes in normal function as well as an individual's response to exposure. Along with other factors, $\mathrm{GxE}$ is implicated as an important contributor to multiple complex diseases including asthma, cardiovascular disease, developmental defects, diabetes, autism spectrum disorder, reproductive defects, and cancer [16,104,153-161]. Many of these diseases have also been tied to endocrine disruptors [76,78,79,84,85,87,89-92,94,99,100]. Studying how gene-environment interactions influence the effects of endocrine disruption could lead to breakthroughs in prevention and treatment of exposure as well as an expanded knowledge base on the mechanisms of these effects.

The interest in gene-environment interactions has been steadily growing, partially due to the advent of affordable and fast next-generation sequencing techniques and the methods to analyze them [157]. GxE studies have proven to be challenging. Oftentimes these studies require large sample sizes and the exposures can be hard to validate or pin down when using human data [162]. Over time though, many effective approaches have been developed to identify GxE. Many GxE study designs have been adopted in the search for GxE. These studies can use data from consortia or single studies and are most often genome-wide association studies using large sample size and can include case-control, case-only, and family data frameworks [119,163-168].

These studies require complex analytical methods to extract information on interactions between the proposed exposures and possible interactions. In recent years, many exciting, and effective methods have begun to arise that increase the power of investigations into GxE.

The earliest experimental designs in genetic studies used family data to try and identify genetic etiologies of disease [169]. This study design has also been leveraged to identify gene-environment interactions [169]. Family data is still important to the field and is used to this day, often in conjunction with sequencing data, to find GxE [166,167]. One study evaluated three different approaches to data analysis, implementing generalized estimating equations (GEE), a hierarchical linear model, and a pedigree-based mixed modeling approach in $\mathrm{R}$, three popular statistical approaches in GxE analysis [166]. This study concluded that these approaches are all comparable in their results but showed that the GEE model may have had increased type-I error [166]. Another study also analyzed the GEE model for family data along with linear mixed-effects models, finding that GEE is more robust against misspecification of exposure, a risk in GxE studies [167]. With the advent of more complex genetic data, the preferred design of GxE studies became the case-control design using unrelated individuals [164]. This design utilizes exposure that causes a specific phenotype and compares individuals who display that phenotype to unaffected individuals.

Wu et al. (2018) attempted to deal with the often hierarchical "main effects, interactions" structure that exists in many GxEs [170]. The researchers assessed the effectiveness of an approach that uses a penalized method with the least absolute deviation loss function, using a simulation and a case study and found that the approach performed well in these circumstances [170]. To overcome the challenges that exist when trying to find rare variants with binary phenotypes, one study used a similarity-based regression method for evaluating GxE interactions that combined data using genetic similarity across markers [129]. Beyond misclassification of exposure, another issue that can arise is the complexity of dealing with multiple exposures. One study proposes a linear mixed model to overcome this [171]. Oftentimes permutation tests are done to avoid error, although one such study used a parametric bootstrap model to avoid the need for permutation tests when that was not possible $[164,172]$. One emerging approach to try and find significant conclusions from such studies is meta-analysis [173]. Meta-analysis-based approaches can leverage the results from multiple similar studies to try and find GxE [173]. 
One early paper exploring GxE methods that used linear modeling and logistic regression for analysis suggests that in the specific scenario that the phenotype is rare, and the causative exposure is independent of the genetics, removing individuals without the phenotype of interest could increase precision [174]. This case-only analysis method has evolved over the years into a tool that can be used to effectively find gene-environment interactions. One problem that arises in case-only analysis is the independence assumption [175-177]. Significant bias can be introduced when the independence of the genetics and the exposure are misclassified $[168,175,177]$. Soon after this initial study Umbach and Weinberg [175] and Chatterjee and Carroll [178] expanded on the method by using multiple maximum likelihood methods for case-only analysis. These studies included scenarios where only cases were sampled, and situations where the independence of exposure and genetics is conditional allowing for some relaxation of the independence assumption. Mukherjee and Chatterjee took advantage of Bayesian methods to relax the independence assumption while maintaining the increased precision of the case-only method [177].

Motivated by the improvements demonstrated by the case-only method while understanding that the independence assumption could, sometimes, not be applied, Murcray et al. proposed a 2-step method that utilized the methods developed for case-only analysis [176]. The first step uses a likelihood ratio test of association between $\mathrm{G}$ and $\mathrm{E}$, taken from case-only tests, to screen for initial SNPs in GWAS data and then uses a traditional GxE test on the SNPs that pass in step 1 [176]. This method utilizes a decrease in the usual multiple testing correction for increased power [176]. This is true even in the case of some G-E dependence because the second step is necessarily unbiased even if the first step incurs some bias [176]. Paré et al. introduced a 2-step method that screens by differences in variance between traits in different genotypes using Levene's test [179]. Zhang et al. compared this method to a method from Kooperburg and LeBlanc, which proposes a 2-step method that leverages marginal effects to screen for gene $\times$ gene interactions, in order to find an effective 2-step method to discover GxE $[165,180]$. They then introduce two new methods: a modified version of the Paré et al. approach looking at variance heterogeneity in the residuals rather than the trait, and a combined version of the two original methods [165]. While all of these approaches provide a robust approach to finding GxE, the evaluation found that in certain situations the Paré et al. approach can have increased type I error [165]. In the case where more than one interaction occurs the variance heterogeneity approach and the joint approach showed increased power over the other methods but were similar to the other approaches or less powerful when only one interaction occurred [165].

Biernacka et al. expanded the 2-step method further by introducing the use of gene-set analysis (GSA) in tandem with a primary screening step [181]. This gene-set approach was initially used for gene-expression studies but is emerging as a powerful method to analyze GWAS data [182-185]. Single-nucleotide polymorphism (SNP) approaches to GWAS are often limited by sample size and may not have the power to find rare variants or variants with small effects $[183,186]$. Gene-sets can be constructed out of SNPs that are associated based on linkage or biological pathways [183]. GSA can be considered self-contained, wherein only the gene-sets are analyzed, and competitive, where SNPs are first analyzed by themselves for significance $[182,183,186]$. Fridley and Biernacka provide an in-depth review of all of the gene-set methods used for GWAS, including one- and two-step methods, introduced prior to the paper's publishing [182]. One study found that when compared, two-step analysis with gene-sets were more powerful than one-step methods [181]. These GSA approaches have been parlayed into a useful approach to identify GxE [184,185]. Tzeng et al. proposed a method to combine SNPs via similarity regression to build a marker set that can be used to identify GxE [187]. This method allows for the investigation of rare and common variants, can account for multiple covariates, and prevents signals that are in opposite directions cancelling each other out [182]. Lin et al. proposed a gene-environment set association test (GESAT) that uses a variance component test to find SNP-set environment interactions along with ridge regression to 
identify main effects [185]. An easy-to-use tool, MAGMA, has even been expanded to do gene-set analysis for GxE [184].

The problems that plague the search for GxE, including small sample sizes, underpowered methods, and misunderstood interaction can contribute to erroneous developments and missed conclusions. To identify GxE that affects susceptibility to endocrine disruptors, the methods used should be well understood and the approach should be tailored to each problem. In the case of susceptibility to thyroid disruption, an under-investigated problem, the issue is many-faceted. The thyroid system is made up of and connected to many complex pathways, the thyroid receptor itself has several isoforms that are known to behave slightly differently. This lends itself to a gene-set analysis method that combines SNPs into pathways, combined with a 2-step approach would allow for a robust and powerful approach to investigating susceptibility to thyroid disruption. Ritchie et al. reviewed methods to include biological knowledge, improving the effectiveness of GxE studies, using approaches that include databases, endophenotypes, and model organisms [188]. The methods discussed in this paper could be used to simplify the complexity of the thyroid pathways to better find GxE that contributes to susceptibility. Searching the thyroid signaling pathway alone the CTD brings up 469 diseases tied to a great many more chemicals, some known endocrine disruptors, but a comparatively smaller 116 genes [122]. Using databases like this could help simplify the analysis of GxE, increasing power these studies.

Existing data can also be used to identify endophenotypes, such as existing geneexpression data, which are closer to the involved genes, but contribute to the etiology of diseases of interest [188]. Model organisms can also simplify the equation by allowing greater control over the environment [189]. A study in zebrafish used high-throughput methods to identify GxE related to exposure to abamectin [119]. Zebrafish allow for the use of high-throughput environmental methods with complex, vertebrate organisms [184]. Leveraging this system could even facilitate the high-throughput discovery of chemicals that exhibit genetically rooted differences in individual susceptibility across a population without any complex sequencing or statistical analysis. Using well-established, familybased experimental designs to assay chemicals and estimate important parameters like heritability could screen out chemicals that are unlikely to exhibit GxE $[190,191]$. Estimating heritability across the population of adverse effects using a well-established method could efficiently identify chemicals for further analysis, using the methods discussed in this paper, in the daunting chemical landscape that exists today. Combining well-established genetics approaches, endophenotypes, biological data, model organisms, high-throughput approaches, and a powerful analysis method such as the 2-step approach could create a compelling method to identify GxE related to endocrine and, particularly, thyroid disruption by punching through the complex pathways involved. Table 1 compares the approaches discussed here. Adding in functional validation to confirm results could be an efficacious approach to uncovering the etiology of thyroid diseases and the factors that contribute to susceptibility.

Table 1. Comparison between methods that are described in the text that can be used to identify GxE. Sub-approaches are presented with over-arching approach that they draw from. Methods are presented with use case situations where they are generally considered useful.

\begin{tabular}{cccc}
\hline Approach & Sub-Approaches & Use Cases & Citation \\
\hline FAMILY-BASED & $\begin{array}{c}\text { generalized estimating } \\
\text { equations }\end{array}$ & $\begin{array}{c}\text { Pedigree data is available and } \\
\text { exposure mis-specification is a } \\
\text { concern }\end{array}$ & $\begin{array}{c}\text { Basson et al. (2016) [161], } \\
\text { Sitlani et al. (2016) [162] }\end{array}$ \\
\cline { 2 - 3 } & heirarchical linear model & $\begin{array}{c}\text { Pedigree data is available and } \\
\text { type I error is a concern }\end{array}$ & $\begin{array}{c}\text { Pedigree data is available and } \\
\text { type I error is a concern }\end{array}$ \\
\hline
\end{tabular}


Table 1. Cont.

\begin{tabular}{|c|c|c|c|}
\hline Approach & Sub-Approaches & Use Cases & Citation \\
\hline \multirow{4}{*}{ CASE-CONTROL } & $\begin{array}{l}\text { Penalized method with least } \\
\text { absolute deviation loss function }\end{array}$ & $\begin{array}{l}\text { When large genome-wide data } \\
\text { is available and hierarchical } \\
\text { "main effects, interactions" } \\
\text { structure is a concern }\end{array}$ & Wu et al. (2018) [165] \\
\hline & Similarity-based regression & $\begin{array}{c}\text { When large genome-wide data } \\
\text { is available and rare-variants } \\
\text { with binary phenotypes are } \\
\text { being investigated }\end{array}$ & Zhao et al. (2015) [124] \\
\hline & linear mixed model & $\begin{array}{l}\text { When large genome-wide data } \\
\text { is available and multiple } \\
\text { exposure are being investigated }\end{array}$ & BIOS Consortium (2016) [166] \\
\hline & Parametric bootstrap & $\begin{array}{l}\text { Removes need for permutation } \\
\text { tests when large genome-wide } \\
\text { data is available }\end{array}$ & $\begin{array}{c}\text { Gauderman et al. (2017) [159], } \\
\text { Coombes et al. (2018) [167] }\end{array}$ \\
\hline \multirow{3}{*}{ CASE-ONLY } & Traditional & $\begin{array}{c}\text { Increases precision when } \\
\text { independence between } \\
\text { exposure and genetics can be } \\
\text { assumed }\end{array}$ & Piegorsch et al. (1994) [169] \\
\hline & Multiple maximum-likelihood & \multirow[b]{2}{*}{$\begin{array}{l}\text { Increases precision and relaxes } \\
\text { independence assumption }\end{array}$} & \multirow{2}{*}{$\begin{array}{l}\text { Umbach and Weinberg (1997) } \\
\text { [170], Chatterjee and Carrol } \\
\text { (2005) [173], Mukherjee and } \\
\text { Chatterjee (2008) [171] }\end{array}$} \\
\hline & Bayesian & & \\
\hline \multirow{4}{*}{ 2-STEP } & $\begin{array}{c}\text { Likelihood ratio to traditional } \\
\text { Levene's test to traditional }\end{array}$ & \multirow{2}{*}{$\begin{array}{l}\text { Increases power and reduces } \\
\text { multiple testing correction in } \\
\text { situations where traditional } \\
\text { case-control or case-case only } \\
\text { approaches would be } \\
\text { appropriate }\end{array}$} & \multirow[b]{2}{*}{$\begin{array}{l}\text { Murcray et al. (2008) [171], } \\
\text { Pare (2010) [174], Kooperburg } \\
\text { and LeBlanc (2008) [175] }\end{array}$} \\
\hline & Marginal effects to traditional & & \\
\hline & Modified Pare et al. & \multirow{2}{*}{$\begin{array}{l}\text { Robust in situations with with } \\
\text { multiple exposure and reduce } \\
\text { type I error versus other 2-step } \\
\text { approaches }\end{array}$} & \multirow[b]{2}{*}{ Zhang et al. (2016) [160] } \\
\hline & $\begin{array}{l}\text { Combined Pare and } \\
\text { Kooperburg }\end{array}$ & & \\
\hline \multirow{3}{*}{$\begin{array}{l}\text { GENE-SET ANALYSIS } \\
\text { (GSA) }\end{array}$} & Traditional & $\begin{array}{c}\text { Increases power versus more } \\
\text { traditional approaches }\end{array}$ & Biernacka et al. (2012) [176] \\
\hline & With similarity regression & $\begin{array}{l}\text { GSA when there are multiple } \\
\text { covariates and opposite effects } \\
\text { that may cancel each other out } \\
\text { are a concern }\end{array}$ & Tzeng et al. (2013) [180] \\
\hline & GESAT & $\begin{array}{l}\text { Established method for user } \\
\text { friendly GSA }\end{array}$ & Lin et al. (2013) [180] \\
\hline META-ANALYSIS & NA & $\begin{array}{l}\text { Situations where investigators } \\
\text { want to combine data from } \\
\text { multiple studies to identify } \\
\text { possible gene-environment } \\
\text { interactions }\end{array}$ & Shi et al. (2017) [168] \\
\hline
\end{tabular}

\section{Conclusions}

Current data on endocrine disruptors and gene-environment interactions are progressing rapidly on their own. Many sources point to genetic influences on the susceptibility of a population to the effects of these exposures, yet few studies have gone beyond the discovery of differential effects of EDCs on genetically diverse populations. This research is especially lacking in relation to thyroid disruptors. The groundwork exists to rapidly discover GxE in the context of EDCs. High throughput techniques to find signals of GxE in model organisms followed with high-dimensional genome-wide investigations could 
rapidly advance our understanding of GxE in this context. A new understanding of differential individual susceptibility to endocrine-disrupting chemicals across populations will help to develop more effective regulatory and mechanistic understandings that go beyond the current paradigm of EDC research to improve prevention and treatment of the adverse effects of exposure.

Author Contributions: Conceptualization and analysis, D.J.W.; data generation and experimental design, L.T., J.L.D., R.L.T.; funding acquisition, R.L.T., D.M.R. All authors contributed to writing, review, and editing. All authors have read and agreed to the published version of the manuscript.

Funding: This research was supported by the National Institutes of Health [P42 ES016465, P30 ES030287, P42 ES031009, P30 ES025128, R56 ES030007, and R01 CA571530] and the Environmental Protection Agency [R835168].

Institutional Review Board Statement: The study was conducted according to the guidelines of the Institutional Review Board of Oregon State University.

Informed Consent Statement: Not applicable.

Data Availability Statement: Data used in the analysis in this paper are available in the supplementary material of Truong et al. (2020) [118].

Conflicts of Interest: The authors declare no conflict of interest. The funders had no role in the design of the study; in the collection, analyses, or interpretation of data; in the writing of the manuscript, or in the decision to publish the results.

\section{References}

1. Diamanti-Kandarakis, E.; Bourguignon, J.P.; Giudice, L.C.; Hauser, R.; Prins, G.S.; Soto, A.M.; Zoeller, R.T.; Gore, A.C. EndocrineDisrupting Chemicals: An Endocrine Society Scientific Statement. Endocr. Rev. 2009, 30, 293-342. [CrossRef] [PubMed]

2. Attina, T.M.; Hauser, R.; Sathyanarayana, S.; Hunt, P.A.; Bourguignon, J.P.; Myers, J.P.; DiGangi, J.; Zoeller, R.T.; Trasande, L. Exposure to endocrine-disrupting chemicals in the USA: A population-based disease burden and cost analysis. Lancet Diabetes Endocrinol. 2016, 4, 996-1003. [CrossRef]

3. Gore, A.C.; Chappell, V.A.; Fenton, S.E.; Flaws, J.A.; Nadal, A.; Prins, G.S.; Toppari, J.; Zoeller, R.T. EDC-2: The Endocrine Society's Second Scientific Statement on Endocrine-Disrupting Chemicals. Endocr. Rev. 2015, 36, E1-E150. [CrossRef] [PubMed]

4. Darbre, P.D. Endocrine Disruptors and Obesity. Curr. Obes. Rep. 2017, 6, 18-27. [CrossRef]

5. Boas, M.; Feldt-Rasmussen, U.; Main, K.M. Thyroid effects of endocrine-disrupting chemicals. Mol. Cell. Endocrinol. 2012, 355, 240-248. [CrossRef]

6. Gutleb, A.C.; Cambier, S.; Serchi, T. Impact of Endocrine Disruptors on the Thyroid Hormone System. Horm. Res. Paediatr. 2016, 86, 271-278. [CrossRef]

7. Alaee, M. An overview of commercially used brominated flame retardants, their applications, their use patterns in different countries/regions and possible modes of release. Environ. Int. 2003, 29, 683-689. [CrossRef]

8. Groh, K.J.; Backhaus, T.; Carney-Almroth, B.; Geueke, B.; Inostroza, P.A.; Lennquist, A.; Leslie, H.A.; Maffini, M.; Slunge, D.; Trasande, L.; et al. Overview of known plastic packaging-associated chemicals and their hazards. Sci. Total Environ. 2019, 651, 3253-3268. [CrossRef] [PubMed]

9. Ewence, A.; Brescia, S.; Johnson, I.; Rumsby, P.C. An approach to the identification and regulation of endocrine-disrupting pesticides. Food Chem. Toxicol. 2015, 78, 214-220. [CrossRef]

10. Witorsch, R.J.; Thomas, J.A. Personal care products and endocrine disruption: A critical review of the literature. Crit. Rev. Toxicol. 2010, 40, 1-30. [CrossRef]

11. Wong, K.H.; Durrani, T.S. Exposures to Endocrine-disrupting Chemicals in Consumer Products-A Guide for Pediatricians. Curr. Probl. Pediatr. Adolesc. Health Care 2017, 47, 107-118. [CrossRef] [PubMed]

12. Carlstedt, F.; Jönsson, B.A.G.; Bornehag, C.-G. PVC flooring is related to human uptake of phthalates in infants: Phthalate uptake in infants. Indoor Air 2013, 23, 32-39. [CrossRef]

13. Koo, H.J.; Lee, B.M. Estimated exposure to phthalates in cosmetics and risk assessment. J. Toxicol. Environ. Health A 2004, 67, 1901-1914. [CrossRef] [PubMed]

14. Fall, T.; Ingelsson, E. Genome-wide association studies of obesity and metabolic syndrome. Mol. Cell. Endocrinol. 2014, 382, 740-757. [CrossRef] [PubMed]

15. Sladek, R.; Rocheleau, G.; Rung, J.; Dina, C.; Shen, L.; Serre, D.; Boutin, P.; Vincent, D.R.; Belisle, A.; Hadjadj, S.; et al. A genome-wide association study identifies novel risk loci for type 2 diabetes. Nature 2007, 445, 881-885. [CrossRef]

16. Axelsson, J.; Bonde, J.P.; Giwercman, Y.L.; Rylander, L.; Giwercman, A. Gene-environment interaction and male reproductive function. Asian J. Androl. 2010, 12, 298-307. [CrossRef] 
17. Colletti, J.A.; Leland-Wavrin, K.M.; Kurz, S.G.; Hickman, M.P.; Seiler, N.L.; Samanas, N.B.; Eckert, Q.A.; Dennison, K.L.; Ding, L.; Schaffer, B.S.; et al. Validation of Six Genetic Determinants of Susceptibility to Estrogen-Induced Mammary Cancer in the Rat and Assessment of Their Relevance to Breast Cancer Risk in Humans. Genes Genomes Genet. 2014, 4, 1385-1394. [CrossRef]

18. Jerry, D.J.; Shull, J.D.; Hadsell, D.L.; Rijnkels, M.; Dunphy, K.A.; Schneider, S.S.; Vandenberg, L.N.; Majhi, P.D.; Byrne, C.; Trentham-Dietz, A. Genetic variation in sensitivity to estrogens and breast cancer risk. Mamm. Genome 2018, 29, 24-37. [CrossRef]

19. Colter, B.T.; Garber, H.F.; Fleming, S.M.; Fowler, J.P.; Harding, G.D.; Hooven, M.K.; Howes, A.A.; Infante, S.K.; Lang, A.L.; MacDougall, M.C.; et al. Ahr and Cyp1a2 genotypes both affect susceptibility to motor deficits following gestational and lactational exposure to polychlorinated biphenyls. Neurotoxicology 2018, 65, 125-134. [CrossRef]

20. Alam, G.; Jones, B.C. Toxicogenetics: In search of host susceptibility to environmental toxicants. Front. Genet. 2014, 5, 327. [CrossRef]

21. Qin, C.; Tanis, K.Q.; Podtelezhnikov, A.A.; Glaab, W.E.; Sistare, F.D.; DeGeorge, J.J. Toxicogenomics in drug development: A match made in heaven? Expert Opin. Drug Metab. Toxicol. 2016, 12, 847-849. [CrossRef] [PubMed]

22. Futran Fuhrman, V.; Tal, A.; Arnon, S. Why endocrine-disrupting chemicals (EDCs) challenge traditional risk assessment and how to respond. J. Hazard. Mater. 2015, 286, 589-611. [CrossRef] [PubMed]

23. Herbst, A.L.; Ulfelder, H.; Poskanzer, D.C. Association of Maternal Stilbestrol Therapy with Tumor Appearance in Young Women. N. Engl. J. Med. 1971, 284, 878-881. [CrossRef]

24. Kiyama, R.; Wada-Kiyama, Y. Estrogenic endocrine disruptors: Molecular mechanisms of action. Environ. Int. 2015, 83, 11-40. [CrossRef]

25. Elshan, N.G.R.D.; Rettig, M.B.; Jung, M.E. Molecules targeting the androgen receptor (AR) signaling axis beyond the AR-Ligand binding domain. Med. Res. Rev. 2019, 39, 910-960. [CrossRef]

26. Luccio-Camelo, D.C.; Prins, G.S. Disruption of androgen receptor signaling in males by environmental chemicals. J. Steroid Biochem. Mol. Biol. 2011, 127, 74-82. [CrossRef]

27. Zhang, J.; Yang, Y.; Liu, W.; Schlenk, D.; Liu, J. Glucocorticoid and mineralocorticoid receptors and corticosteroid homeostasis are potential targets for endocrine-disrupting chemicals. Environ. Int. 2019, 133, 105133. [CrossRef]

28. Kamstra, J.H.; Hruba, E.; Blumberg, B.; Janesick, A.; Mandrup, S.; Hamers, T.; Legler, J. Transcriptional and Epigenetic Mechanisms Underlying Enhanced in Vitro Adipocyte Differentiation by the Brominated Flame-Retardant BDE-47. Environ. Sci. Technol. 2014, 48, 4110-4119. [CrossRef] [PubMed]

29. Guo, Y.; Zhou, B. Thyroid endocrine system disruption by pentachlorophenol: An in vitro and in vivo assay. Aquat. Toxicol. 2013, 142-143, 138-145. [CrossRef] [PubMed]

30. Mangelsdorf, D.J.; Thummel, C.; Beato, M.; Herrlich, P.; Schütz, G.; Umesono, K.; Blumberg, B.; Kastner, P.; Mark, M.; Chambon, P.; et al. The nuclear receptor superfamily: The second decade. Cell 1995, 83, 835-839. [CrossRef]

31. Helsen, C.; Kerkhofs, S.; Clinckemalie, L.; Spans, L.; Laurent, M.; Boonen, S.; Vanderschueren, D.; Claessens, F. Structural basis for nuclear hormone receptor DNA binding. Mol. Cell. Endocrinol. 2012, 348, 411-417. [CrossRef] [PubMed]

32. Näär, A.M.; Boutin, J.-M.; Lipkin, S.M.; Yu, V.C.; Holloway, J.M.; Glass, C.K.; Rosenfeld, M.G. The orientation and spacing of core DNA-binding motifs dictate selective transcriptional responses to three nuclear receptors. Cell 1991, 65, 1267-1279. [CrossRef]

33. Denayer, S.; Helsen, C.; Thorrez, L.; Haelens, A.; Claessens, F. The Rules of DNA Recognition by the Androgen Receptor. Mol. Endocrinol. 2010, 24, 898-913. [CrossRef] [PubMed]

34. Malo, M.S.; Zhang, W.; Alkhoury, F.; Pushpakaran, P.; Abedrapo, M.A.; Mozumder, M.; Fleming, E.; Siddique, A.; Henderson, J.W.; Hodin, R.A. Thyroid Hormone Positively Regulates the Enterocyte Differentiation Marker Intestinal Alkaline Phosphatase Gene via an Atypical Response Element. Mol. Endocrinol. 2004, 18, 1941-1962. [CrossRef] [PubMed]

35. Toyoda, N.; Zavacki, A.M.; Maia, A.L.; Harney, J.W.; Larsen, P.R. A novel retinoid X receptor-independent thyroid hormone response element is present in the human type 1 deiodinase gene. Mol. Cell. Biol. 1995, 15, 5100-5112. [CrossRef]

36. Umesono, K.; Murakami, K.K.; Thompson, C.C.; Evans, R.M. Direct repeats as selective response elements for the thyroid hormone, retinoic acid, and vitamin D3 receptors. Cell 1991, 65, 1255-1266. [CrossRef]

37. Verrijdt, G.; Schoenmakers, E.; Haelens, A.; Peeters, B.; Verhoeven, G.; Rombauts, W.; Claessens, F. Change of Specificity Mutations in Androgen-selective Enhancers: Evidence for a Role of Differential DNA Binding by the Androgen Receptor. J. Biol. Chem. 2000, 275, 12298-12305. [CrossRef]

38. Verrijdt, G. Selective DNA recognition by the androgen receptor as a mechanism for hormone-specific regulation of gene expression. Mol. Genet. Metab. 2003, 78, 175-185. [CrossRef]

39. Umesono, K.; Evans, R.M. Determinants of target gene specificity for steroid/thyroid hormone receptors. Cell 1989, 57, 1139-1146. [CrossRef]

40. Yamamoto, K.R. Steroid receptor regulated transcription of specific genes and gene networks. Annu. Rev. Genet. 1985, 19, 209-252. [CrossRef]

41. Lemaire, G.; Mnif, W.; Mauvais, P.; Balaguer, P.; Rahmani, R. Activation of $\alpha$ - and $\beta$-estrogen receptors by persistent pesticides in reporter cell lines. Life Sci. 2006, 79, 1160-1169. [CrossRef] [PubMed]

42. Kleinstreuer, N.C.; Ceger, P.; Watt, E.D.; Martin, M.T.; Houck, K.A.; Browne, P.; Thomas, R.S.; Casey, W.M.; Dix, D.J.; Allen, D.; et al. Development and Validation of a Computational Model for Androgen Receptor Activity. Chem. Res. Toxicol. 2017, 30, 946-964. [CrossRef] [PubMed] 
43. Judson, R.S.; Magpantay, F.M.; Chickarmane, V.; Haskell, C.; Tania, N.; Taylor, J.; Xia, M.; Huang, R.; Rotroff, D.M.; Filer, D.L.; et al. Integrated Model of Chemical Perturbations of a Biological Pathway Using 18 In Vitro High-Throughput Screening Assays for the Estrogen Receptor. Toxicol. Sci. 2015, 148, 137-154. [CrossRef] [PubMed]

44. Diel, P.; Olff, S.; Schmidt, S.; Michna, H. Molecular Identification of Potential Selective Estrogen Receptor Modulator (SERM) Like Properties of Phytoestrogens in the Human Breast Cancer Cell Line MCF-7. Planta Med. 2001, 67, 510-514. [CrossRef]

45. Katzenellenbogen, S.; Montano, M.; Ediger, R. Estrogen Receptors: Selective Ligands, Partners, and Distinctive Pharmacology. Recent Prog. Horm. Res. 2000, 55, 163-195.

46. Katzenellenbogen, B.S.; Katzenellenbogen, J.A.; Mordecai, D. Zearalenones: Characterization of the estrogenic potencies and receptor interactions of a series of fungal beta-resorcylic acid lactones. Endocrinology 1979, 105, 33-40. [CrossRef]

47. Combarnous, Y.; Nguyen, T.M.D. Comparative Overview of the Mechanisms of Action of Hormones and Endocrine Disruptor Compounds. Toxics 2019, 7, 5. [CrossRef]

48. Katzenellenbogen, B.S.; Choi, I.; Delage-Mourroux, R.; Ediger, T.R.; Martini, P.G.; Montano, M.; Sun, J.; Weis, K.; A Katzenellenbogen, J. Molecular mechanisms of estrogen action: Selective ligands and receptor pharmacology. J. Steroid Biochem. Mol. Biol. 2000, 74, 279-285. [CrossRef]

49. Kurz, S.G.; Hansen, K.K.; McLaughlin, M.T.; Shivaswamy, V.; Schaffer, B.S.; Gould, K.A.; McComb, R.D.; Meza, J.L.; Shull, J.D. Tissue-Specific Actions of the Ept1, Ept2, Ept6, and Ept9 Genetic Determinants of Responsiveness to Estrogens in the Female Rat. Endocrinology 2008, 149, 3850-3859. [CrossRef]

50. Dutertre, M.; Smith, C.L. Molecular Mechanisms of Selective Estrogen Receptor Modulator (SERM) Action. Sel. Estrogen Recept. Modul. 2000, 295, 7.

51. Heldring, N.; Pike, A.; Andersson, S.; Matthews, J.; Cheng, G.; Hartman, J.; Tujague, M.; Ström, A.; Treuter, E.; Warner, M.; et al. Estrogen Receptors: How Do They Signal and What Are Their Targets. Physiol. Rev. 2007, 87, 905-931. [CrossRef] [PubMed]

52. Gustafsson, J.-Å. What pharmacologists can learn from recent advances in estrogen signalling. Trends Pharmacol. Sci. 2003, 24, 479-485. [CrossRef]

53. Hall, J.M.; Couse, J.F.; Korach, K.S. The Multifaceted Mechanisms of Estradiol and Estrogen Receptor Signaling. J. Biol. Chem. 2001, 276, 36869-36872. [CrossRef]

54. Jänne, O.A.; Shan, L.-X. Structure and Function of the Androgen Receptor. Ann. N. Y. Acad. Sci. 1991, 626, 81-91. [CrossRef] [PubMed]

55. Matsumoto, T.; Shiina, H.; Kawano, H.; Sato, T.; Kato, S. Androgen receptor functions in male and female physiology. J. Steroid Biochem. Mol. Biol. 2008, 109, 236-241. [CrossRef] [PubMed]

56. Wyce, A.; Bai, Y.; Nagpal, S.; Thompson, C.C. Research Resource: The Androgen Receptor Modulates Expression of Genes with Critical Roles in Muscle Development and Function. Mol. Endocrinol. 2010, 24, 1665-1674. [CrossRef]

57. Mhaouty-Kodja, S. Role of the androgen receptor in the central nervous system. Mol. Cell. Endocrinol. 2018, 465, 103-112. [CrossRef] [PubMed]

58. O'Hara, L.; Smith, L.B. Androgen receptor roles in spermatogenesis and infertility. Best Pract. Res. Clin. Endocrinol. Metab. 2015, 29, 595-605. [CrossRef] [PubMed]

59. Mooradian, A.D.; Morley, J.E.; Korenman, S.G. Biological Actions of Androgens. Endocr. Rev. 1987, 8, 1-28. [CrossRef]

60. Lynch, C.; Sakamuru, S.; Huang, R.; Stavreva, D.A.; Varticovski, L.; Hager, G.L.; Judson, R.S.; Houck, K.A.; Kleinstreuer, N.C.; Casey, W.; et al. Identifying environmental chemicals as agonists of the androgen receptor by using a quantitative high-throughput screening platform. Toxicology 2017, 385, 48-58. [CrossRef] [PubMed]

61. Liao, S.; Liang, T.; Fang, S.; Castañeda, E.; Shao, T.-C. Steroid structure and androgenic activity specificities involved in the receptor binding and nuclear retention of various androgens. J. Biol. Chem. 1973, 248, 6154-6162. [CrossRef]

62. Janne, O.A.; US Department of Health and Human Services; National Institute on Drug Abuse. Androgen Interaction through Multiple Steroid Receptors: (496332006-010). In PsycEXTRA Dataset; American Psychological Association (APA): Washington, DC, USA, 1990. [CrossRef]

63. Shaffer, P.L.; Jivan, A.; Dollins, D.E.; Claessens, F.; Gewirth, D.T. Structural basis of androgen receptor binding to selective androgen response elements. Proc. Natl. Acad. Sci. USA 2004, 101, 4758-4763. [CrossRef] [PubMed]

64. Brent, G.A. Mechanisms of thyroid hormone action. J. Clin. Investig. 2012, 122, 3035-3043. [CrossRef] [PubMed]

65. Cheng, S.-Y.; Leonard, J.L.; Davis, P.J. Molecular aspects of thyroid hormone actions. Endocr. Rev. 2010, 31, 139-170. [CrossRef]

66. Anyetei-Anum, C.S.; Roggero, V.R.; Allison, L.A. Thyroid hormone receptor localization in target tissues. J. Endocrinol. 2018, 237, R19-R34. [CrossRef] [PubMed]

67. Mitsuhashi, T.; Tennyson, G.E.; Nikodem, V.M. Alternative splicing generates messages encoding rat c-erbA proteins that do not bind thyroid hormone. Proc. Natl. Acad. Sci. USA 1988, 85, 5804-5808. [CrossRef]

68. Williams, G.R. Cloning and Characterization of Two Novel Thyroid Hormone Receptor Isoforms. Mol. Cell. Biol. 2000, 20, 14. [CrossRef]

69. Astapova, I.; Hollenberg, A.N. The in vivo role of nuclear receptor corepressors in thyroid hormone action. Biochim. Biophys. Acta BBA Gen. Subj. 2013, 1830, 3876-3881. [CrossRef]

70. Hong, H.; Kohli, K.; Garabedian, M.J.; Stallcup, M.R. GRIP1, a transcriptional coactivator for the AF-2 transactivation domain of steroid, thyroid, retinoid, and vitamin D receptors. Mol. Cell. Biol. 1997, 17, 2735-2744. [CrossRef] 
71. Liu, Y.-Y.; Brent, G.A. Thyroid hormone crosstalk with nuclear receptor signaling in metabolic regulation. Trends Endocrinol. Metab. 2010, 21, 166-173. [CrossRef]

72. Williams, G.R. Neurodevelopmental and Neurophysiological Actions of Thyroid Hormone. J. Neuroendocrinol. 2008, 20, 784-794. [CrossRef] [PubMed]

73. Mullur, R.; Liu, Y.-Y.; Brent, G.A. Thyroid Hormone Regulation of Metabolism. Physiol. Rev. 2014, 94, 355-382. [CrossRef] [PubMed]

74. Oetting, A.; Yen, P.M. New insights into thyroid hormone action. Best Pract. Res. Clin. Endocrinol. Metab. 2007, 21, 193-208. [CrossRef] [PubMed]

75. Braun, J.M. Early-life exposure to EDCs: Role in childhood obesity and neurodevelopment. Nat. Rev. Endocrinol. 2017, 13, 161-173 [CrossRef]

76. Marí-Bauset, S.; Donat-Vargas, C.; Llópis-González, A.; Marí-Sanchis, A.; Peraita-Costa, I.; Llopis-Morales, J.; Morales-SuárezVarela, M. Endocrine Disruptors and Autism Spectrum Disorder in Pregnancy: A Review and Evaluation of the Quality of the Epidemiological Evidence. Children 2018, 5, 157. [CrossRef] [PubMed]

77. Howard, S.G. Developmental Exposure to Endocrine-disrupting Chemicals and Type 1 Diabetes Mellitus. Front. Endocrinol. 2018, 9, 513. [CrossRef]

78. Lind, P.M.; Lind, L. Endocrine-disrupting chemicals and risk of diabetes: An evidence-based review. Diabetologia 2018, 61, 1495-1502. [CrossRef] [PubMed]

79. Kajta, M.; Wójtowicz, A.K. Impact of endocrine-disrupting chemicals on neural development and the onset of neurological disorders. Pharmacol. Rep. PR 2013, 65, 1632-1639. [CrossRef]

80. Webb, E.; Moon, J.; Dyrszka, L.; Rodriguez, B.; Cox, C.; Patisaul, H.; Bushkin, S.; London, E. Neurodevelopmental and neurological effects of chemicals associated with unconventional oil and natural gas operations and their potential effects on infants and children. Rev. Environ. Health 2018, 33, 3-29. [CrossRef]

81. Zhu, B.; Zhao, G.; Yang, L.; Zhou, B. Tetrabromobisphenol A caused neurodevelopmental toxicity via disrupting thyroid hormones in zebrafish larvae. Chemosphere 2018, 197, 353-361. [CrossRef]

82. Tyagi, P.; James-Todd, T.; Mínguez-Alarcón, L.; Ford, J.B.; Keller, M.; Petrozza, J.; Calafat, A.M.; Hauser, R.; Williams, P.L.; Bellavia, A. Identifying Windows of Susceptibility to Endocrine Disrupting Chemicals in Relation to Gestational Weight Gain among Pregnant Women Attending a Fertility Clinic. Environ. Res. 2021, 194, 110638. [CrossRef] [PubMed]

83. Predieri, B.; Bruzzi, P.; Bigi, E.; Ciancia, S.; Madeo, S.F.; Lucaccioni, L.; Iughetti, L. Endocrine Disrupting Chemicals and Type 1 Diabetes. IJMS 2020, 21, 2937. [CrossRef] [PubMed]

84. Terry, M.B.; Michels, K.B.; Brody, J.G.; Byrne, C.; Chen, S.; Jerry, D.J.; Malecki, K.M.C.; Martin, M.B.; Miller, R.L.; Neuhausen, S.L.; et al. Environmental Exposures during Windows of Susceptibility for Breast Cancer: A Framework for Prevention Research. Breast Cancer Res. 2019, 21, 96. [CrossRef] [PubMed]

85. Li, M.-C.; Chen, C.-H.; Guo, Y.L. Phthalate esters and childhood asthma: A systematic review and congener-specific meta-analysis. Environ. Pollut. 2017, 229, 655-660. [CrossRef] [PubMed]

86. Benjamin, S.; Masai, E.; Kamimura, N.; Takahashi, K.; Anderson, R.C.; Faisal, P.A. Phthalates impact human health: Epidemiological evidences and plausible mechanism of action. J. Hazard. Mater. 2017, 340, 360-383. [CrossRef] [PubMed]

87. Paciência, I.; Rufo, J.C.; Silva, D.; Martins, C.; Mendes, F.; Farraia, M.; Delgado, L.; Fernandes, E.D.O.; Padrão, P.; Moreira, P.; et al. Exposure to indoor endocrine-disrupting chemicals and childhood asthma and obesity. Allergy 2019, 74, 1277-1291. [CrossRef] [PubMed]

88. Omran, G.A.; Gaber, H.D.; Mostafa, N.A.M.; Abdel-Gaber, R.M.; Salah, E.A. Potential hazards of bisphenol A exposure to semen quality and sperm DNA integrity among infertile men. Reprod. Toxicol. 2018, 81, 188-195. [CrossRef] [PubMed]

89. Humblet, O.; Birnbaum, L.; Rimm, E.; Mittleman, M.A.; Hauser, R. Dioxins and Cardiovascular Disease Mortality. Environ. Health Perspect. 2008, 116, 1443-1448. [CrossRef]

90. Hu, W.-Y.; Shi, G.-B.; Hu, D.-P.; Nelles, J.L.; Prins, G.S. Actions of estrogens and endocrine-disrupting chemicals on human prostate stem/progenitor cells and prostate cancer risk. Mol. Cell. Endocrinol. 2012, 354, 63-73. [CrossRef]

91. Rachoń, D. Endocrine-disrupting chemicals (EDCs) and female cancer: Informing the patients. Rev. Endocr. Metab. Disord. 2015, 16, 359-364. [CrossRef]

92. Tan, M.E.; Li, J.; Xu, H.E.; Melcher, K.; Yong, E. Androgen receptor: Structure, role in prostate cancer and drug discovery. Acta Pharmacol. Sin. 2015, 36, 3-23. [CrossRef] [PubMed]

93. Moeller, L.C.; Führer, D. Thyroid hormone, thyroid hormone receptors, and cancer: A clinical perspective. Endocr. Relat. Cancer 2013, 20, R19-R29. [CrossRef] [PubMed]

94. Calsolaro, V.; Pasqualetti, G.; Niccolai, F.; Caraccio, N.; Monzani, F. Thyroid Disrupting Chemicals. IJMS 2017, 18, 2583. [CrossRef]

95. Okamura, K.; Taurog, A.; Krulich, L. Strain Differences among Rats in Response to Remington Iodine-Deficient Diets. Endocrinology 1981, 109, 458-463. [CrossRef] [PubMed]

96. Penhale, W.J.; Farmer, A.; Irvine, W.J. Thyroiditis in T cell-depleted rats. Influence of strain, radiation dose, adjuvants and antilymphocyte serum. Clin. Exp. Immunol. 1975, 21, 362-375.

97. Larsen, M.C.; Brake, P.B.; Parmar, D.; Jefcoate, C.R. The Induction of Five Rat Hepatic P450 Cytochromes by Phenobarbital and Similarly Acting Compounds Is Regulated by a Sexually Dimorphic, Dietary-Dependent Endocrine Factor That Is Highly Strain Specific. Arch. Biochem. Biophys. 1994, 315, 24-34. [CrossRef] 
98. Ikegwuonu, F.I.; Ganem, L.G.; Larsen, M.C.; Shen, X.; Jefcoate, C.R. The Regulation by Gender, Strain, Dose, and Feeding Status of the Induction of Multiple Forms of Cytochrome P450 Isozymes in Rat Hepatic Microsomes by $2,4,5,2^{\prime}, 4^{\prime}, 5^{\prime}$-Hexachlorobiphenyl. Toxicol. Appl. Pharmacol. 1996, 139, 33-41. [CrossRef]

99. Simanainen, U. Adult 2,3,7,8-Tetrachlorodibenzo-p-Dioxin (TCDD) Exposure and Effects on Male Reproductive Organs in Three Differentially TCDD-Susceptible Rat Lines. Toxicol. Sci. 2004, 81, 401-407. [CrossRef]

100. Simanainen, U.; Haavisto, T.; Tuomisto, J.T.; Paranko, J.; Toppari, J.; Tuomisto, J.; Peterson, R.E.; Viluksela, M. Pattern of Male Reproductive System Effects After in Utero and Lactational 2,3,7,8-Tetrachlorodibenzo-p-dioxin (TCDD) Exposure in Three Differentially TCDD-Sensitive Rat Lines. Toxicol. Sci. 2004, 80, 101-108. [CrossRef]

101. Spearow, J.L. Genetic Variation in Susceptibility to Endocrine Disruption by Estrogen in Mice. Science 1999, $285,1259-1261$. [CrossRef]

102. Spearow, J.L.; O’Henley, P.; Doemeny, P.; Sera, R.; Leffler, R.; Sofos, T.; Barkley, M. Genetic variation in physiological sensitivity to estrogen in mice. APMIS 2001, 109, S289-S297. [CrossRef]

103. Cummings, A.M.; Kavlock, R.J. Gene-Environment Interactions: A Review of Effects on Reproduction and Development. Crit. Rev. Toxicol. 2004, 34, 461-485. [CrossRef] [PubMed]

104. Duan, Q.L.; Du, R.; Lasky-Su, J.; Klanderman, B.J.; Partch, A.B.; Peters, S.P.; Irvin, C.G.; Hanrahan, J.P.; Lima, J.J.; Blake, K.V.; et al. A polymorphism in the thyroid hormone receptor gene is associated with bronchodilator response in asthmatics. Pharmacogenomics J. 2013, 13, 130-136. [CrossRef] [PubMed]

105. Kalikiri, M.K.; Mamidala, M.P.; Rao, A.N.; Rajesh, V. Analysis and functional characterization of sequence variations in ligand binding domain of thyroid hormone receptors in autism spectrum disorder (ASD) patients: Thyroid Hormone Receptor Mutations in ASD Patients. Autism Res. 2017, 10, 1919-1928. [CrossRef] [PubMed]

106. Alberobello, A.T.; Congedo, V.; Liu, H.; Cochran, C.; Skarulis, M.C.; Forrest, D.; Celi, F.S. An intronic SNP in the thyroid hormone receptor $b$ gene is associated with pituitary cell-specific over-expression of a mutant thyroid hormone receptor b2 (R338W) in the index case of pituitary-selective resistance to thyroid hormone. J. Transl. Med. 2011, 7, 144. [CrossRef]

107. Safer, J.D. The Thyroid Hormone Receptor-Gene Mutation R383H Is Associated with Isolated Central Resistance to Thyroid Hormone. J. Clin. Endocrinol. Metab. 1999, 84, 3099-3109. [CrossRef]

108. Kiss-Toth, E.; Harlock, E.; Lath, D.; Quertermous, T.; Wilkinson, J.M. A TNF Variant that Associates with Susceptibility to Musculoskeletal Disease Modulates Thyroid Hormone Receptor Binding to Control Promoter Activation. PLoS ONE 2013, 8 , e76034. [CrossRef]

109. Puzianowska-Kuznicka, M.; Krystyniak, A.; Madej, A.; Cheng, S.-Y.; Nauman, J. Functionally Impaired TR Mutants Are Present in Thyroid Papillary Cancer. J. Clin. Endocrinol. Metab. 2002, 87, 1120-1128. [CrossRef]

110. Szymański, Ł.; Matak, D.; Bartnik, E.; Szczylik, C.; Czarnecka, A.M. Thyroid Hormones as Renal Cell Cancer Regulators. J. Signal Transduct. 2016, 2016, 1362407. [CrossRef]

111. Lin, K.-H.; Shieh, H.-Y.; Chen, S.-L.; Hsu, H.-C. Expression of mutant thyroid hormone nuclear receptors in human hepatocellular carcinoma cells. Mol. Carcinog. 1999, 26, 53-61. [CrossRef]

112. Erf, G.F.; Marsh, J.A. Effect of dietary triiodothyronine on mixed-lymphocyte responsiveness in young male chickens. Dev. Comp. Immunol. 1989, 13, 177-186. [CrossRef]

113. Liu, Y.; Qu, K.; Hai, Y.; Li, X.; Zhao, L.; Zhao, C. SNP mutations occurring in thyroid hormone receptor influenced individual susceptibility to triiodothyronine: Molecular dynamics and site-directed mutagenesis approaches. J. Cell. Biochem. 2018, 119, 2604-2616. [CrossRef]

114. Darnerud, P.O. Brominated flame retardants as possible endocrine disrupters. Int. J. Androl. 2008, 31, 152-160. [CrossRef]

115. Legler, J. Are brominated flame retardants endocrine disruptors? Environ. Int. 2003, 29, 879-885. [CrossRef]

116. Eggesbø, M.; Thomsen, C.; Jørgensen, J.V.; Becher, G.; Odland, J.Ø.; Longnecker, M.P. Associations between brominated flame retardants in human milk and thyroid-stimulating hormone (TSH) in neonates. Environ. Res. 2011, 111, 737-743. [CrossRef]

117. Kronborg, T.M.; Hansen, J.F.; Rasmussen, Å.K.; Vorkamp, K.; Nielsen, C.H.; Frederiksen, M.; Hofman-Bang, J.; Hahn, C.H.; Ramhøj, L.; Feldt-Rasmussen, U. The flame-retardant DE-71 (a mixture of polybrominated diphenyl ethers) inhibits human differentiated thyroid cell function in vitro. PLoS ONE 2017, 12, e0179858. [CrossRef]

118. Truong, L.; Marvel, S.; Reif, D.M.; Thomas, D.G.; Pande, P.; Dasgupta, S.; Simonich, M.T.; Waters, K.M.; Tanguay, R.L. The multi-dimensional embryonic zebrafish platform predicts flame retardant bioactivity. Reprod. Toxicol. 2020, 96, 359-369. [CrossRef]

119. Balik-Meisner, M.; Truong, L.; Scholl, E.H.; La Du, J.K.; Tanguay, R.L.; Reif, D.M. Elucidating Gene-by-Environment Interactions Associated with Differential Susceptibility to Chemical Exposure. Environ. Health Perspect. 2018, 126, 067010. [CrossRef]

120. Gelissen, I.C.; McLachlan, A.J. The pharmacogenomics of statins. Pharmacol. Res. 2014, 88, 99-106. [CrossRef]

121. Kitzmiller, J.; Mikulik, E.; Dauki, A.; Mukherjee, C.; Luzum, J. Pharmacogenomics of statins: Understanding susceptibility to adverse effects. Pharm. Pers. Med. 2016, 9, 97-106. [CrossRef]

122. Davis, A.P.; Grondin, C.J.; Johnson, R.J.; Sciaky, D.; McMorran, R.; Wiegers, J.; Wiegers, T.C.; Mattingly, C.J. The Comparative Toxicogenomics Database: Update 2019. Nucleic Acids Res. 2019, 47, D948-D954. [CrossRef]

123. Crump, D.; Porter, E.; Egloff, C.; Williams, K.L.; Letcher, R.J.; Gauthier, L.T.; Kennedy, S.W. 1,2-Dibromo-4-(1,2-dibromoethyl)cyclohexane and tris(methylphenyl) phosphate cause significant effects on development, mRNA expression, and circulating bile acid concentrations in chicken embryos. Toxicol. Appl. Pharmacol. 2014, 277, 279-287. [CrossRef] 
124. Kitamura, S.; Kato, T.; Iida, M.; Jinno, N.; Suzuki, T.; Ohta, S.; Fujimoto, N.; Hanada, H.; Kashiwagi, K.; Kashiwagi, A. Anti-thyroid hormonal activity of tetrabromobisphenol A, a flame retardant, and related compounds: Affinity to the mammalian thyroid hormone receptor, and effect on tadpole metamorphosis. Life Sci. 2005, 76, 1589-1601. [CrossRef]

125. Thomas, M.B.; Stapleton, H.M.; Dills, R.L.; Violette, H.D.; Christakis, D.A.; Sathyanarayana, S. Demographic and dietary risk factors in relation to urinary metabolites of organophosphate flame retardants in toddlers. Chemosphere 2017, 185, 918-925. [CrossRef]

126. Wang, Q.; Lam, J.C.; Han, J.; Wang, X.; Guo, Y.; Lam, P.K.; Zhou, B. Developmental exposure to the organophosphorus flameretardant tris(1,3-dichloro-2-propyl) phosphate: Estrogenic activity, endocrine disruption and reproductive effects on zebrafish. Aquat. Toxicol. 2015, 160, 163-171. [CrossRef]

127. Ma, Z.; Yu, Y.; Tang, S.; Liu, H.; Su, G.; Xie, Y.; Giesy, J.P.; Hecker, M.; Yu, H. Differential modulation of expression of nuclear receptor mediated genes by tris(2-butoxyethyl) phosphate (TBOEP) on early life stages of zebrafish (Danio rerio). Aquat. Toxicol. 2015, 169, 196-203. [CrossRef]

128. Sun, H.; Xu, L.-C.; Chen, J.-F.; Song, L.; Wang, X.-R. Effect of bisphenol a, tetrachlorobisphenol A and pentachlorophenol on the transcriptional activities of androgen receptor-mediated reporter gene. Food Chem. Toxicol. 2006, 44, 1916-1921. [CrossRef]

129. Zhao, G.; Marceau, R.; Zhang, D.; Tzeng, J.-Y. Assessing Gene-Environment Interactions for Common and Rare Variants with Binary Traits Using Gene-Trait Similarity Regression. Genetics 2015, 199, 695-710. [CrossRef]

130. Zhu, Y.; Ma, X.; Su, G.; Yu, L.; Letcher, R.J.; Hou, J.; Yu, H.; Giesy, J.P.; Liu, C. Environmentally Relevant Concentrations of the Flame-Retardant Tris(1,3-dichloro-2-propyl) Phosphate Inhibit Growth of Female Zebrafish and Decrease Fecundity. Environ. Sci. Technol. 2015, 49, 14579-14587. [CrossRef]

131. Dishaw, L.V.; JMacaulay, L.; Roberts, S.C.; Stapleton, H.M. Exposures, mechanisms, and impacts of endocrine-active flame retardants. Curr. Opin. Pharmacol. 2014, 19, 125-133. [CrossRef]

132. Kojima, H.; Takeuchi, S.; Itoh, T.; Iida, M.; Kobayashi, S.; Yoshida, T. In vitro endocrine disruption potential of organophosphate flame retardants via human nuclear receptors. Toxicology 2013, 314, 76-83. [CrossRef]

133. National Toxicology Program. NTP Toxicology and Carcinogenesis Studies of Tetrakis(hydroxymethyl)phosphonium sulfate (THPS) (CAS No. 55566-30-8) and Tetrakis(hydroxymethyl)phosphonium chloride (THPC) (CAS No. 124-64-1) in F344/N Rats and B6C3F1 Mice (Gavage Studies). Natl. Toxicol. Program Tech. Rep. Ser. 1987, 296, 1-290.

134. Böckers, M.; Paul, N.W.; Efferth, T. Organophosphate ester tri-o-cresyl phosphate interacts with estrogen receptor $\alpha$ in MCF-7 breast cancer cells promoting cancer growth. Toxicol. Appl. Pharmacol. 2020, 395, 114977. [CrossRef]

135. Chupeau, Z.; Bonvallot, N.; Mercier, F.; Le Bot, B.; Chevrier, C.; Glorennec, P. Organophosphorus Flame Retardants: A Global Review of Indoor Contamination and Human Exposure in Europe and Epidemiological Evidence. Int. J. Environ. Res. Public. Health 2020, 17, 6713. [CrossRef]

136. Xu, Q.; Wu, D.; Dang, Y.; Yu, L.; Liu, C.; Wang, J. Reproduction impairment and endocrine disruption in adult zebrafish (Danio rerio) after waterborne exposure to TBOEP. Aquat. Toxicol. 2017, 182, 163-171. [CrossRef]

137. Wang, Y.; Zhang, W.; Li, A.; Song, M. Tetrachlorobisphenol A induced immunosuppression and uterine injury in mice. Ecotoxicol. Environ. Saf. 2021, 207, 111527. [CrossRef] [PubMed]

138. Reers, A.R.; Eng, M.L.; Williams, T.D.; Elliott, J.E.; Cox, M.E.; Beischlag, T.V. The Flame-Retardant Tris(1,3-dichloro-2-propyl) Phosphate Represses Androgen Signaling in Human Prostate Cancer Cell Lines: EFFECT OF TDCIPP ON ANDROGEN SIGNALING. J. Biochem. Mol. Toxicol. 2016, 30, 249-257. [CrossRef] [PubMed]

139. Liu, Y.; Li, Y.; Dong, S.; Han, L.; Guo, R.; Fu, Y.; Zhang, S.; Chen, J. The risk and impact of organophosphate esters on the development of female-specific cancers: Comparative analysis of patients with benign and malignant tumors. J. Hazard. Mater. 2021, 404, 124020. [CrossRef]

140. Sugeng, E.J.; de Cock, M.; Leonards, P.E.G.; van de Bor, M. Toddler behavior, the home environment, and flame-retardant exposure. Chemosphere 2020, 252, 126588. [CrossRef]

141. Hu, L.; Peng, T.; Huang, J.; Su, T.; Luo, R.; Zheng, Y.; Zhong, Z.; Yu, P.; Nie, K.; Zheng, L. Tri-ortho-cresyl phosphate (TOCP) induced ovarian failure in mice is related to the Hippo signaling pathway disruption. Reprod. Toxicol. 2019, 83, 21-27. [CrossRef]

142. Egloff, C.; Crump, D.; Porter, E.; Williams, K.L.; Letcher, R.J.; Gauthier, L.T.; Kennedy, S.W. Tris(2-butoxyethyl)phosphate and triethyl phosphate alter embryonic development, hepatic mRNA expression, thyroid hormone levels, and circulating bile acid concentrations in chicken embryos. Toxicol. Appl. Pharmacol. 2014, 279, 303-310. [CrossRef] [PubMed]

143. U.S. Environmental Protection Agency. CompTox Chemicals Dashboard. Available online: https://comptox.epa.gov/dashboard/ DTXSID0021331 (accessed on 23 June 2020).

144. U.S. Environmental Protection Agency. CompTox Chemicals Dashboard. Available online: https://comptox.epa.gov/dashboard/ DTXSID4021391 (accessed on 23 June 2020).

145. U.S. Environmental Protection Agency. CompTox Chemicals Dashboard. Available online: https://comptox.epa.gov/dashboard/ DTXSID5021330 (accessed on 23 June 2020).

146. U.S. Environmental Protection Agency. CompTox Chemicals Dashboard. Available online: https://comptox.epa.gov/dashboard/ DTXSID5021413 (accessed on 23 June 2020).

147. U.S. Environmental Protection Agency. CompTox Chemicals Dashboard. Available online: https://comptox.epa.gov/dashboard/ DTXSID5021758 (accessed on 23 June 2020). 
148. U.S. Environmental Protection Agency. CompTox Chemicals Dashboard. Available online: https://comptox.epa.gov/dashboard/ DTXSID3021770 (accessed on 23 June 2020).

149. U.S. Environmental Protection Agency. CompTox Chemicals Dashboard. Available online: https://comptox.epa.gov/dashboard/ DTXSID3024861 (accessed on 23 June 2020).

150. U.S. Environmental Protection Agency. CompTox Chemicals Dashboard. Available online: https://comptox.epa.gov/dashboard/ DTXSID4028880 (accessed on 23 June 2020).

151. U.S. Environmental Protection Agency. CompTox Chemicals Dashboard. Available online: https://comptox.epa.gov/dashboard/ DTXSID4030047 (accessed on 23 June 2020).

152. U.S. Environmental Protection Agency. CompTox Chemicals Dashboard. Available online: https://comptox.epa.gov/dashboard/ DTXSID6032192 (accessed on 23 June 2020).

153. Huang, T.; Hu, F.B. Gene-environment interactions and obesity: Recent developments and future directions. BMC Med. Genom. 2015, 8, S2. [CrossRef] [PubMed]

154. Lee, J.-U.; Kim, J.D.; Park, C.-S. Gene-Environment Interactions in Asthma: Genetic and Epigenetic Effects. Yonsei Med. J. 2015, 56, 877. [CrossRef] [PubMed]

155. Lovely, C.; Rampersad, M.; Fernandes, Y.; Eberhart, J. Gene-environment interactions in development and disease: Geneenvironment interactions in development and disease. Wiley Interdiscip. Rev. Dev. Biol. 2017, 6, e247. [CrossRef] [PubMed]

156. Kim, J.-W.; Park, K.; Kang, R.J.; Gonzales, E.L.; Oh, H.A.; Seung, H.; Ko, M.J.; Cheong, J.H.; Chung, C.; Shin, C.Y. Geneenvironment interaction counterbalances social impairment in mouse models of autism. Sci. Rep. 2019, 9, 11490. [CrossRef]

157. Heianza, Y.; Qi, L. Impact of Genes and Environment on Obesity and Cardiovascular Disease. Endocrinology 2019, 160, 81-100. [CrossRef] [PubMed]

158. Krauss, R.S.; Hong, M. Gene-Environment Interactions and the Etiology of Birth Defects. In Current Topics in Developmental Biology; Elsevier: Amsterdam, The Netherlands, 2016; Volume 116, pp. 569-580.

159. Rudolph, A.; Chang-Claude, J.; Schmidt, M.K. Gene-environment interaction and risk of breast cancer. Br. J. Cancer 2016, 114, 125-133. [CrossRef]

160. Simonds, N.I.; Ghazarian, A.A.; Pimentel, C.B.; Schully, S.D.; Ellison, G.L.; Gillanders, E.M.; Mechanic, L.E. Review of the Gene-Environment Interaction Literature in Cancer: What Do We Know?: Gene-Environment Interaction Literature Review. Genet. Epidemiol. 2016, 40, 356-365. [CrossRef]

161. Zafarmand, M.H.; Tajik, P.; Spijker, R.; Agyemang, C. Gene-environment interaction on the risk of type 2 diabetes among ethnic minority populations living in Europe and North America: A systematic review. Curr. Diabetes Rev. 2020, 16, 457-470. [CrossRef] [PubMed]

162. McAllister, K.; Mechanic, L.E.; Amos, C.; Aschard, H.; Blair, I.A.; Chatterjee, N.; Conti, D.; Gauderman, W.J.; Hsu, L.; Hutter, C.M.; et al. Current Challenges and New Opportunities for Gene-Environment Interaction Studies of Complex Diseases. Am. J. Epidemiol. 2017, 186, 753-761. [CrossRef]

163. Simon, P.H.G.; Sylvestre, M.-P.; Tremblay, J.; Hamet, P. Key Considerations and Methods in the Study of Gene-Environment Interactions. Am. J. Hypertens. 2016, 29, 891-899. [CrossRef]

164. Gauderman, W.J.; Mukherjee, B.; Aschard, H.; Hsu, L.; Lewinger, J.P.; Patel, C.J.; Witte, J.S.; Amos, C.; Tai, C.G.; Conti, D.; et al. Update on the State of the Science for Analytical Methods for Gene-Environment Interactions. Am. J. Epidemiol. 2017, 186, 762-770. [CrossRef] [PubMed]

165. Zhang, P.; Lewinger, J.P.; Conti, D.; Morrison, J.L.; Gauderman, W.J. Detecting Gene-Environment Interactions for a Quantitative Trait in a Genome-Wide Association Study: Detecting Gene-Environment Interactions for a Quantitative. Genet. Epidemiol. 2016, 40, 394-403. [CrossRef] [PubMed]

166. Basson, J.; Sung, Y.J.; de Las Fuentes, L.; Schwander, K.L.; Vazquez, A.; Rao, D.C. Three Approaches to Modeling GeneEnvironment Interactions in Longitudinal Family Data: Gene-Smoking Interactions in Blood Pressure: Gene-Smoking Interactions in Blood Pressure. Genet. Epidemiol. 2016, 40, 73-80. [CrossRef]

167. Sitlani, C.M.; Dupuis, J.; Rice, K.M.; Sun, F.; Pitsillides, A.N.; Cupples, L.A.; Psaty, B.M. Genome-wide gene-environment interactions on quantitative traits using family data. Eur. J. Hum. Genet. 2016, 24, 1022-1028. [CrossRef]

168. Meisner, A.; Kundu, P.; Chatterjee, N. Case-Only Analysis of Gene-Environment Interactions Using Polygenic Risk Scores. Am. J. Epidemiol. 2019, 188, 2013-2020. [CrossRef] [PubMed]

169. Thompson, E.A. Genetic epidemiology: A review of the statistical basis. Stat. Med. 1986, 5, 291-302. [CrossRef]

170. Wu, C.; Jiang, Y.; Ren, J.; Cui, Y.; Ma, S. Dissecting gene-environment interactions: A penalized robust approach accounting for hierarchical structures. Stat. Med. 2018, 37, 437-456. [CrossRef]

171. Moore, R.; Casale, F.P.; Bonder, M.J.; Horta, D.; Franke, L.; Barroso, I.; Stegle, O. A linear mixed-model approach to study multivariate gene-environment interactions. Nat. Genet. 2019, 51, 180-186. [CrossRef]

172. Coombes, B.J.; Biernacka, J.M. Application of the parametric bootstrap for gene-set analysis of gene-environment interactions. Eur. J. Hum. Genet. 2018, 26, 1679-1686. [CrossRef]

173. Shi, G.; Nehorai, A. Robustness of meta-analyses in finding gene $\times$ environment interactions. PLoS ONE 2017, $12, \mathrm{e} 0171446$.

174. Piegorsch, W.W.; Weinberg, C.R.; Taylor, J.A. Non-hierarchical logistic models and case-only designs for assessing susceptibility in population-based case-control studies. Stat. Med. 1994, 13, 153-162. [CrossRef] 
175. Chatterjee, N.; Carroll, R.J. Semiparametric maximum likelihood estimation exploiting gene-environment independence in case-control studies. Biometrika 2005, 92, 399-418. [CrossRef]

176. Murcray, C.E.; Lewinger, J.P.; Gauderman, W.J. Gene-Environment Interaction in Genome-Wide Association Studies. Am. J. Epidemiol. 2008, 169, 219-226. [CrossRef] [PubMed]

177. Mukherjee, B.; Chatterjee, N. Exploiting Gene-Environment Independence for Analysis of Case-Control Studies: An Empirical Bayes-Type Shrinkage Estimator to Trade-Off between Bias and Efficiency. Biometrics 2008, 64, 685-694. [CrossRef] [PubMed]

178. Umbach, D.M.; Weinberg, C.R. Designing and analysing case-control studies to exploit independence of genotype and exposure. Stat. Med. 1997, 16, 13. [CrossRef]

179. Paré, G.; Cook, N.R.; Ridker, P.M.; Chasman, D.I. On the Use of Variance per Genotype as a Tool to Identify Quantitative Trait Interaction Effects: A Report from the Women's Genome Health Study. PLoS Genet. 2010, 6, e1000981. [CrossRef] [PubMed]

180. Kooperberg, C.; LeBlanc, M. Increasing the power of identifying gene $\times$ gene interactions in genome-wide association studies. Genet. Epidemiol. 2008, 32, 255-263. [CrossRef]

181. Biernacka, J.M.; Jenkins, G.D.; Wang, L.; Moyer, A.M.; Fridley, B.L. Use of the gamma method for self-contained gene-set analysis of SNP data. Eur. J. Hum. Genet. 2012, 20, 565-571. [CrossRef]

182. Fridley, B.L.; Biernacka, J.M. Gene set analysis of SNP data: Benefits, challenges, and future directions. Eur. J. Hum. Genet. 2011, 19, 837-843. [CrossRef]

183. Wang, K.; Li, M.; Hakonarson, H. Analysing biological pathways in genome-wide association studies. Nat. Rev. Genet. 2010, 11, 843-854. [CrossRef] [PubMed]

184. De Leeuw, C.A.; Mooij, J.M.; Heskes, T.; Posthuma, D. MAGMA: Generalized Gene-Set Analysis of GWAS Data. PLoS Comput. Biol. 2015, 11, e1004219. [CrossRef] [PubMed]

185. Lin, X.; Lee, S.; Christiani, D.C.; Lin, X. Test for interactions between a genetic marker set and environment in generalized linear models. Biostatistics 2013, 14, 667-681. [CrossRef]

186. Wang, K.; Li, M.; Bucan, M. Pathway-Based Approaches for Analysis of Genomewide Association Studies. Am. J. Hum. Genet. 2007, 81, 1278-1283. [CrossRef] [PubMed]

187. Tzeng, J.-Y.; Zhang, D.; Pongpanich, M.; Smith, C.; McCarthy, M.I.; Sale, M.M.; Worrall, B.B.; Hsu, F.-C.; Thomas, D.C.; Sullivan, P.F. Studying Gene and Gene-Environment Effects of Uncommon and Common Variants on Continuous Traits: A Marker-Set Approach Using Gene-Trait Similarity Regression. Am. J. Hum. Genet. 2011, 89, 277-288. [CrossRef]

188. Ritchie, M.D.; Davis, J.R.; Aschard, H.; Battle, A.; Conti, D.; Du, M.; Eskin, E.; Fallin, M.D.; Hsu, L.; Kraft, P.; et al. Incorporation of Biological Knowledge into the Study of Gene-Environment Interactions. Am. J. Epidemiol. 2017, 186, 771-777. [CrossRef]

189. Garcia, G.R.; Noyes, P.D.; Tanguay, R.L. Advancements in zebrafish applications for 21st century toxicology. Pharmacol. Ther. 2016, 161, 11-21. [CrossRef]

190. Falconer, D.S. Introduction to Quantitative Genetics; Longman, Scientific; Technical: Burnt Mill, Harlow, UK; Wiley: New York, NY, USA, 1989.

191. Tenesa, A.; Haley, C.S. The heritability of human disease: Estimation, uses and abuses. Nat. Rev. Genet. 2013, 14, 139-149. [CrossRef] 